\title{
Community engagement in US and Canadian medical schools
}

This article was published in the following Dove Press journal:

Advances in Medical Education and Practice

19 January 2011

Number of times this article has been viewed

\section{Adam O Goldstein \\ Rachel Sobel Bearman \\ Department of Family Medicine, University of North Carolina School of Medicine, Chapel Hill, NC, USA}

Correspondence: Adam O Goldstein Department of Family Medicine, University of North Carolina School of Medicine, CB 7595, Chapel Hill, NC 27599-7595, USA

$\mathrm{Tel}+\mid$ 919-966-4090

$\mathrm{Fax}+1$ 919-966-6125

Email aog@med.unc.edu
Introduction: This study examines the integration of community engagement and community-engaged scholarship at all accredited US and Canadian medical schools in order to better understand and assess their current state of engagement.

Methods: A 32-question data abstraction instrument measured the role of community engagement and community-engaged scholarship as represented on the Web sites of all accredited US and Canadian medical schools. The instrument targeted a medical school's mission and vision statements, institutional structure, student and faculty awards and honors, and faculty tenure and promotion guidelines.

Results: Medical school Web sites demonstrate little evidence that schools incorporate community engagement in their mission or vision statements or their promotion and tenure guidelines. The majority of medical schools do not include community service terms and/or descriptive language in their mission statements, and only $8.5 \%$ of medical schools incorporate community service and engagement as a primary or major criterion in promotion and tenure guidelines.

Discussion: This research highlights significant gaps in the integration of community engagement or community-engaged scholarship into medical school mission and vision statements, promotion and tenure guidelines, and service administrative structures.

Keywords: medical school, education, community service, mission, tenure, engagement

\section{Introduction}

The medical profession has a responsibility 'to define and organize the educational and standard-setting processes for current and future members'. ${ }^{1}$ Medical education must be able to meet the challenges that society presents and be able to implement and sustain changes and improvements in its education system to meet and overcome those challenges. ${ }^{2}$ A challenge for medical professionals is simultaneously improving the personal health of their patients as well as the health care system that benefits all society.

Strengthening linkages between physicians and the communities they serve can help address pressing health problems in the society, such as inadequate access to health care, lack of health insurance, and health disparities. ${ }^{3,4}$ Combining the resources of the academic health care system with the experience and knowledge of the community can also create powerful partnerships for healthier communities and increase community engagement by medical schools. ${ }^{2-4}$ However, increased engagement between physicians and their communities presents unique challenges to academic medical institutions that attempt to combine new commitments to community engagement 
with traditional medical school missions in clinical care, research, and education. The rigor of medical education and the competition for tenure and promotion among academic physicians may not easily fit with a new commitment to community engagement.

Despite calls for greater engagement, ${ }^{5-9}$ neither academic medicine nor the medical practice environment has embraced community engagement into its clinical, educational, or research activities. ${ }^{10}$ Numerous reasons exist for the relative lack of engagement in medical schools. ${ }^{1-14}$ Thus, most physicians or physicians-in-training receive little training or practical experiences in community engagement. ${ }^{2}$ To prepare physicians to assume these roles, medical schools must incorporate the meaning, purpose, and benefit of community engagement into an already tight curriculum; reexamine their institutional structures that benefit or hinder engagement; and undertake the difficult task of revamping tenure and promotion policies. ${ }^{4,12,13,15}$

To date, no research has examined to what extent medical schools accredited by the Association of American Medical Colleges (AAMC) integrate community engagement into their mission and vision statements, promotion and tenure guidelines, and administrative structures. This study utilized medical schools' Web sites to examine their commitments and processes surrounding community engagement. Previous studies have utilized the Internet as a means of data extraction, recognizing that Internet is a legitimate resource base and means for dissemination of an institution's values and ideas. ${ }^{16,17}$

While Web sites may not encompass a medical school in its totality, they are a medical school's representation of itself to potential and current medical students, faculty, and the larger community. Many have online application services, and all are linked through the AAMC Web site. Thus, the level of community engagement apparent on a medical school's Web site should indicate the relative importance of community engagement to an institution.

\section{Methods}

\section{Population}

The study examined community engagement at 125 US and 17 Canadian accredited medical schools as represented on their Web sites and through the AAMC (www.aamc.org). A 32-question data abstraction instrument targeted the role of community engagement and community-engaged scholarship in medical schools by focusing on a medical school's mission and vision, institutional structure, student and faculty awards and honors, and faculty tenure and promotion guidelines.
We pilot-tested the instrument on 10 US medical school Web sites and refined it based on the results. The study received approval by the Institutional Review Board at the University of North Carolina School of Medicine. It occurred from February to May 2006.

\section{Definitions}

We identified search terms based on the current literature and definitions describing the role of universities in serving diverse communities. ${ }^{7,11,12}$ Community engagement is the application of institutional resources to address and solve challenges facing communities through collaboration with these communities. Community-engaged scholarship is a scholarship that involves the faculty member in a mutually beneficial partnership with the community. Communityengaged scholarship can be transdisciplinary and often integrates some combination of multiple forms of scholarship, integrating combinations of the scholarship of teaching, discovery, integration, application, and engagement. ${ }^{18}$

\section{Searching procedures}

The medical school (or university) Web site search engine was utilized to search key data abstraction terms. For each term searched, we reviewed the first 30 returns. We also identified key data by following links on the medical school Web site. In those instances, we found data through given links versus specified search terms. If a medical school's tenure and promotion policies were not accessible by internal school search engines, we conducted a Google-based Web search to identify the policy. Some schools' promotion and tenure polices were passcode blocked or not found despite these procedures.

Answers to questions pertaining to finite data points, such as NIH funding levels, medical school student and faculty size, AAMC Outstanding Community Service Awards, and AAMC Caring for Community Grant Awards, were gathered from online sources. ${ }^{19-22}$ Institutional commitment to engagement included evidence of a professional and/or institutional structure dedicated to promoting and/or maintaining community service/engagement/partnerships with the community, such as a Dean of Engagement or an Office of Community Service in the medical school.

\section{Coding}

Coding for medical school mission and vision examined the presence of community engagement as represented through utilization of four phrases: 'community service', 'service', 'public service', and/or 'community engagement' in the 
mission and vision statements. We did not specifically include subsets of community service, such as 'community-oriented primary care', as these subsets are restricted to individual departments with medical centers (ie, family or community medicine or school of public health mission statements) and may not reflect the underlying medical school mission or vision, and almost always if they exist, occur within the context of a 'service' search term. We coded the level of community engagement as the degree to which these phrases and their accompanying language comprised the entire mission or vision statement.

Coding for promotion and tenure policies represented levels of engagement in the promotion and tenure guidelines, ranging from the highest value showing community engagement or community-engaged scholarship as the primary criterion for promotion and tenure, to the lowest value showing it not mentioned in consideration of promotion and tenure.

One investigator initially coded all 142 Web instruments. Two investigators reviewed and independently coded any questions on variables. In these cases, the investigators compared responses, discussed differences, and determined a final coding.

\section{Analysis}

Frequency distributions for all variables utilized SPSS, v14 (SPSS, Somers, NY, USA). Bivariate analyses utilized chi-square test for categorical variables, Pearson's correlation coefficients for continuous variables, and analysis of variance ( $F$ statistic) for comparing means. Stepwise logistic regression models examined the effects of independent variables (NIH funding, public/private school, size of faculty and student body, prescience of administrative structures on service) on the medical school mission statements and promotion and tenure guidelines.

\section{Results}

All 125 US medical schools and 17 Canadian medical schools have Web sites, and $87 \%$ have a search engine on their Web site. A total of $70 \%$ of medical schools are public, $71 \%$ have a school or program in public health, the mean faculty size is 932 (range 67-5365), and the mean student size is 542 (range 165-1322). Among US medical schools, the mean NIH research funding in 2004 was $\$ 83.2$ million (range \$1.2-\$403 million) and 55\% had an Area Health Education Center (AHEC) affiliation. The overwhelming majority of medical schools $(89.1 \%)$ demonstrate one or more community partnerships on their Web sites.
Overall, two-thirds of medical schools have a medical school-based (52.6\%) or a university-based (16.8\%) service administrative structure (ie, office or lead professional) (Table 1). Slightly less than one-half of schools give out either faculty or student awards for community service. Fewer medical schools have additional structures suggestive of commitments to community service, such as a community service honor society, a journal dedicated to community service, or faculty awards for community-engaged scholarship. The presence of a service administrative structure has no relationship to type of school (public or private), presence of an AHEC or School of Public Health, medical school class size, medical school faculty size, or the level of NIH funding.

Twelve US medical schools (9.6\%) have received an AAMC award for Outstanding Community Service (Table 1). Receiving the award strongly relates to having a medical school-based administrative structure to support community service. Eleven of the 12 awards went to a medical school with a medical school-based service administrative structure, and the other to a medical school with a university-based service administrative structure $\left(\chi^{2}=7.24 ; P=0.027\right)$. Receiving an AAMC award for Outstanding Community Service has no relationship with medical school type, presence of an AHEC, or affiliation with a School of Public Health.

Table I Administrative structures and recognition for community engagement at US and Canadian medical schools $(\mathrm{N}=142)^{\prime}$

\begin{tabular}{|c|c|}
\hline Structure & Number (\%) \\
\hline \multicolumn{2}{|l|}{ Associate Dean ${ }^{2}$ or Office of Service } \\
\hline Medical school-based & $72(52.6)$ \\
\hline University-based & $23(16.8)$ \\
\hline None & $42(30.7)$ \\
\hline \multicolumn{2}{|l|}{ Faculty awards for community service } \\
\hline Yes & $46(33.6)$ \\
\hline No & $91(66.4)$ \\
\hline \multicolumn{2}{|l|}{ Faculty awards for community-engaged scholarship ${ }^{3}$} \\
\hline Yes & $4(2.9)$ \\
\hline No & $133(97.1)$ \\
\hline \multicolumn{2}{|l|}{ Student awards for community service } \\
\hline Yes & $62(45.3)$ \\
\hline No & $75(54.7)$ \\
\hline \multicolumn{2}{|l|}{ Community service honor society } \\
\hline Yes & $\mathrm{I}(0.8)$ \\
\hline No & $132(99.2)$ \\
\hline \multicolumn{2}{|l|}{ Journal or magazine dedicated to service } \\
\hline Yes & $12(8.8)$ \\
\hline No & $125(9 \mid .2)$ \\
\hline $\begin{array}{l}\text { Recipient of an AAMC medical school award } \\
\text { for outstanding community service }\end{array}$ & $12(9.6)$ \\
\hline Recipient of AAMC Community of Caring Award & $51(40.8)$ \\
\hline
\end{tabular}

Notes: 'Up to nine medical schools had missing data for one of the variables; ${ }^{2}$ Varied titles given to a designated professional in lead position for service; ${ }^{3} \mathrm{Awards}$ could include receiving an institutional grant for service activity. 
Fifty-one medical schools (40.8\%) had received an AAMC Community of Caring award. Receiving an AAMC Community of Caring award has no relationship with medical school type, presence of an AHEC, affiliation with a School of Public Health, or receiving an AAMC award for Outstanding Community Service. Medical schools with a medical school-based service administrative structure are significantly more likely to receive an AAMC Community of Caring award than those with a university-based service administrative structure or those without any service administrative structure $\left(\chi^{2}=3.18 ; P=0.043\right)$.

Table 2 depicts the presence of engagement language in medical school mission and vision statements. The majority of medical schools do not include community service terms and/or descriptive language in their mission statement. The mission statements of only 12 medical schools (8.6\%) and the vision statement of 1 medical school $(0.7 \%)$ contained clearly delineated engagement language representing at least $20 \%$ of the mission statement. Thirty-eight (27\%) medical school mission statements and $18(12.9 \%)$ vision statements contain none of the identified community service terms but utilize language that infers service to the community. Noticeably, $61.9 \%$ of medical schools lack a vision statement on their Web site.

Private medical schools are significantly less likely to have service terms or descriptive language included in their mission statements compared to public medical schools (64\% vs $\left.38 \%, \chi^{2}=8.47 ; P=0.014\right)$. Medical schools with higher NIH funding are significantly less likely to have mission statements with engagement or community service language $(F=5.89 ; P=0.032)$. Medical schools with larger numbers of faculty are also significantly less likely to have mission

Table 2 Mission and vision statements supporting community engagement in US and Canadian medical schools $(\mathrm{N}=142)^{\prime}$

\begin{tabular}{llc}
\hline Category & \multicolumn{2}{c}{ Number (\%) } \\
\cline { 2 - 3 } & Mission & Vision \\
\hline $\begin{array}{l}\text { Engagement language clearly delineated and } \\
\text { representing at least 20\% of statement }\end{array}$ & $12(8.6)$ & $\mathrm{I}(0.7)$ \\
$\begin{array}{l}\text { Engagement language clearly delineated and } \\
\text { representing less than 20\% of statement }\end{array}$ & $10(7.1)$ & $4(2.9)$ \\
$\begin{array}{l}\text { Community service terms included but no } \\
\text { descriptive language }\end{array}$ & $16(11.4)$ & $4(2.9)$ \\
$\begin{array}{l}\text { Community service terms not included but } \\
\text { language present inferring service to community }\end{array}$ & $38(27.1)$ & $18(12.9)$ \\
$\begin{array}{l}\text { No service terms or descriptions included } \\
\text { in statement }\end{array}$ & $58(41.4)$ & $26(18.7)$ \\
No statement identified & $6(4.3)$ & $86(61.9)$ \\
\hline
\end{tabular}

Note: 'Three medical schools' mission or vision statements not included because of lack of search engine or foreign language. statements with engagement or community service language $(F=6.94 ; P=0.10)$.

In logistic regression analysis, medical schools with higher NIH funding, those with larger faculty sizes, and those that are private are more likely to have mission statements with no service terms or service descriptive language in their mission statements. No relationship exists between a medical school's mission and vision statements and the presence of a service administrative structure or whether the medical school is Canadian or US based.

As depicted in Table 3, only $8.5 \%$ of medical schools incorporate community service and engagement as a primary or major criterion in promotion and tenure guidelines. No medical school specifically incorporates community-engaged scholarship as a primary or major criterion in promotion and tenure guidelines. Alternatively, $41 \%$ of medical schools do not mention community service or engagement and $89.7 \%$ do not mention community-engaged scholarship in their promotion and tenure guidelines. Medical school incorporation of community engagement in promotion and tenure guidelines is related to medical school incorporation of community-engaged scholarship in promotion and tenure guidelines $(r=0.241 ; P=0.009)$.

A larger medical school faculty size is inversely related to medical school consideration of community service and engagement as a criterion in promotion and tenure guidelines ( $r=0.303 ; P=0.001)$ and directly relates to medical schools' mission $(r=0.328 ; P=0.000)$ and vision statements ( $r=0.385 ; P=0.000)$. Medical school vision statements are related to the incorporation of community-engaged

Table 3 Promotion and tenure guidelines relating to community service and community engagement at US and Canadian medical schools $(\mathrm{N}=142)^{\prime}$

\begin{tabular}{|c|c|c|}
\hline \multirow[t]{2}{*}{ Category } & \multicolumn{2}{|l|}{ Number (\%) } \\
\hline & $\begin{array}{l}\text { Community } \\
\text { service and } \\
\text { engagement }\end{array}$ & $\begin{array}{l}\text { Community- } \\
\text { engaged } \\
\text { scholarship }\end{array}$ \\
\hline $\begin{array}{l}\text { Used as a primary or major } \\
\text { criteria in promotion or tenure }\end{array}$ & $10(8.5)$ & - \\
\hline $\begin{array}{l}\text { An area of excellence or one } \\
\text { of a set of standards included } \\
\text { in promotion and tenure }\end{array}$ & $30(25.6)$ & $3(2.6)$ \\
\hline $\begin{array}{l}\text { Taken into consideration in } \\
\text { promotion and tenure but is } \\
\text { not a primary criteria or one } \\
\text { of a set of standards }\end{array}$ & $29(24.8)$ & $9(7.7)$ \\
\hline $\begin{array}{l}\text { Not mentioned in consideration } \\
\text { of promotion and tenure }\end{array}$ & $48(41.0)$ & $105(89.7)$ \\
\hline
\end{tabular}

Note: 'A total of 25 medical schools did not have their promotion and tenure guidelines accessible online. 
scholarship in promotion and tenure guidelines $(r=0.178$; $P=0.054)$. In logistic regression analysis, faculty size and medical school mission statements remain independent predictors of community service and engagement as criterion in promotion and tenure guidelines.

\section{Discussion}

It is the responsibility of medical schools to educate, train, and prepare future physicians to meet the challenges of their profession, including engagement about societal issues which affect the health of communities. ${ }^{1}$ In order for future physicians to meet these challenges, they must understand the importance of community, see their peers and faculty engaging with the community, and have experience in community engagement. ${ }^{4,13,17,22}$

Research has suggested that community-based experiences can increase the likelihood that medical students and residents will develop positive and lasting attitudes about their professional responsibilities in the communities in which they live and practice. ${ }^{22}$ The Liaison Committee for Medical Education adopted a new standard in 2008 to encourage all medical schools to further their community engagement in medical education. The standard states that 'Medical schools should make available sufficient opportunities for medical students to participate in service-learning activities, and should encourage and support student participation'. ${ }^{23}$ While this is an important first step, service-learning opportunities alone will not institutionalize community engagement.

Community engagement cannot become a priority in academic medicine until it is a core mission of the medical school and is reflected in appointment, tenure, and promotion guidelines. The incorporation of engagement into an institution may require a paradigm shift for some medical schools and academic health centers away from more traditional models of medical education, research, and promotion and tenure. . $^{13,17,24,25}$

Mission statements define an organization's purpose and are utilized to articulate its direction and goals. ${ }^{23,26}$ Focusing on the mission statements of a group of similar organizations should reflect the current ideological or philosophical focus of those organizations. ${ }^{23}$ Our research suggests that most medical schools in the United States and Canada have not sufficiently valued community engagement to incorporate this construct into their mission.

Vision statements are distinguishable from mission statements in that they describe a future desirable state or goal. ${ }^{23}$ Since the majority of medical schools had no vision statements accessible online, it was impossible to fully assess the role of engagement in medical school vision statements. Our research highlights a need for medical schools throughout the United States and Canada to examine their mission and vision statements to strengthen their language of engagement and the role of community engagement vis-à-vis other accepted medical school missions of clinical care, teaching, and research.

Despite the lack of community engagement as a core value of the mission of most medical schools, the majority of schools are promoting community service with awards, community partnerships, or service administrative structures. While many medical schools (or their universities) had an administrative structure or office-supporting service, few identifiable faculty awards existed for community engagement or community-engaged scholarship, and less than half offered student awards. This potentially points to a disconnection between the encouragement of community engagement and the lack of faculty and/or students recognition for engagement.

A medical school's values are most clearly articulated in promotion and tenure guidelines, and these guidelines define core measures of success for the faculty. ${ }^{27}$ The notable absence of community engagement and community-engaged scholarship effectively discourages engagement, sending a clear message that faculty time is better spent and rewarded on other pursuits. In this context, it is not surprising that schools whose promotion and tenure guidelines did not mention the scholarship of engagement (similar to those schools without commitments to engagement in their mission statements) were more likely to be those with higher levels of NIH funding.

Direct pressure from outside foundations or funding sources could be a driving force for change within an institution. For instance, those that subsidize medical education at the state or federal level should note that public medical schools are more likely to include engagement language in their mission statements than private institutions, and conversely, schools that are private have higher NIH funding and larger faculty sizes are more likely to have no service terms or service descriptive language in their mission statements. Foundations or government agencies can potentially affect the incorporation of community engagement at private medical schools by making the institutionalization of community engagement or community-engaged scholarship one criteria for funding, similar to how they have utilized other commitments to social policy (eg, gender and ethnicity inclusion, community participation) in funding priorities. 
All medical schools and academic health centers should consider how they can incorporate community engagement and community-engaged scholarship into their promotion and tenure policies. The fact that schools with stronger mission and vision statements around engagement have stronger promotion and tenure guidelines for the scholarship of engagement reinforces the face validity to the suggestion that medical schools consider both constructs as ways to strengthen their institutional commitment to community engagement.

Several medical schools have initiated programs to recognize and incorporate community engagement in their institutions. The Community Engaged Scholarship for Health Collaborative, started in 2005, consisting of 10 health professional schools, including Vanderbilt University School of Medicine, seeks to change 'institutional culture and incentives to realize the promise of the engaged campus' ${ }^{28}$

Several limitations exist with this study. First, for the purpose of this survey, the definition of the term 'service' inferred community engagement, not care to individuals in practice settings, primary service to the university, or the concept of medicine as a service profession. Many medical schools utilize a definition of service linked solely to the provision of clinical care. Second, data collection involved utilizing medical schools' Web sites and the Internet for primary data abstraction. While this data collection technique is novel, it could underestimate the activities that are occurring at any given time on community engagement, and it thus should receive validation by actual activities that are occurring. However, this data collection technique could also overestimate actual accomplishments that have occurred by crediting activities based on the Web site without knowing when they occurred or their magnitude of impact. Such limitations may be lowered by the pervasive use of the Web by universities to share information and advertise their institution to their potential and current faculty and students and the larger community. While concerns could exist that wealthier medical schools might have better Web sites, with more information posted, the fact that this study found an inverse relationship between medical school NIH funding and indicators of engagement makes this concern unlikely. Third, only one coder initially coded all Web sites. However, to limit bias, two coders reviewed any Web sites where questions existed, and a small sample of sites without questions were reviewed by the second coder without any changes occurring. Finally, while this study occurred in 2006, and the need for updated data is already apparent, the pressing financial pressures on medical schools for clinical income has likely limited substantive gains in service promotion in the intervening time period. A recent study also found that a 'social mission score' of medical schools varied widely and was also inversely associated with NIH funding. ${ }^{29}$

To create community-engaged physicians in the future, medical education must broadly integrate the skills and attitudes of good citizenship. ${ }^{30}$ Concepts of community engagement and community-engaged scholarship can assist this integration by creating dynamic new systems of learning and partnership between medical schools and communities.

\section{Acknowledgment}

Both authors are affiliated with the University of North Carolina at Chapel Hill. Both collaborated on the design, implementation, and writing of the research project. Both had access to all research data. This research received funding from the Kenan Leave Sabbatical Program of the University of North Carolina at Chapel Hill.

\section{Disclosure}

The authors report no conflicts of interest in this work.

\section{References}

1. Weiser CJ, Houglum L. Scholarship unbound for the 21st century. J Extension. 1998;36(4):1-5.

2. Whitcomb ME. What community-based education can teach tomorrow's doctors. Acad Med. 2005;80(4):315-316.

3. Fox CE, Morford TG, Fine A, Gibbons MC. The Johns Hopkins Urban Health Institute: a collaborative response to urban health issues. Acad Med. 2004;79(12):1169-1174.

4. Meyer D, Armstrong-Coben A, Batista M. How a community-based organization and an academic health center are creating an effective partnership for training and service. Acad Med. 2005;80(4):327-333.

5. Declaration of Professional Responsibility: Medicine's Social Contact with Humanity. American Medical Association; 2001. Available from: http://www.amaassn.org/ama/upload/mm/369/declaration.pdf. Accessed Jul 172007

6. Principles of Medical Ethics. American Medical Association. Available from: http://www.ama-assn.org/ama/pub/category/2512.html. Accessed Jul 172007.

7. The Community-Engaged Scholarship for Health Collaborative. Community-Campus Partnerships for Health. Available from: http://depts. washington.edu/ccph/healthcollab.html. Accessed Aug 2007.

8. Horton R. The doctor's role in advocacy. Lancet. 2002;359(9305):458.

9. Rothman DJ. Medical professionalism - focusing on the real issues. N Engl J Med. 2000;342(17):1284-1286.

10. Gruen RL, Pearson SD, Brennan TA. Physician-citizens - public roles and professional obligations. JAMA. 2004;291(1):94-98.

11. Calleson DC, Jordan C, Seifer SD. Community-engaged scholarship: is faculty work in communities a true academic enterprise? Acad Med. 2005;80(4):317-321.

12. Calleson DC, Seifer SD, Maurana C. Forces affecting community involvement of AHCs: perspectives of institutional and faculty leaders. Acad Med. 2002;77(1):72-81.

13. Wolff M, Maurana CA. Building effective community-academic partnerships to improve health: a qualitative study of perspectives from communities. Acad Med. 2001;76(2):166-172. 
14. Nora LM, Pomeroy C, Curry TE Jr, Hill NS, Tibbs PA, Wilson EA. Revising appointment, promotion, and tenure procedures to incorporate an expanded definition of scholarship: the University of Kentucky College of Medicine experience. Acad Med. 2000;75(9):913-924.

15. O'Toole TP, Kathuria N, Mishra M, Schukart D. Teaching professionalism within a community context: perspectives from a national demonstration project. Acad Med. 2005;80(4):339-343.

16. Lewkonia RM. The missions of medical schools: the pursuit of health in the service of society. BMC Med Educ. 2001;1:4.

17. Bhat-Schelbert K, Lipsky MS, Steele H, Sharp LK. Mission statements: what do they tell us about family medicine training programs? Fam Med. 2004;36(4):243-247.

18. Commission on Community-Engaged Scholarship in the Health Professions. Linking Scholarship and Communities: Report of the Commission on Community-Engaged Scholarship in the Health Professions. Seattle: Community-Campus Partnerships for Health; 2005.

19. NIH Awards to Medical Schools by Rank: Fiscal Year 2004. Available from: http://grants.nih.gov/grants/award/rank/medttl04.htm. Accessed Mar 2006

20. FACTS - Applicants, Matriculants and Graduates, Total Enrollment by Sex and School, 2001-2005. Association of American Medical Colleges. Available from: http://www.aamc.org/data/facts/2005/factsenrl.htm. Accessed Mar 2006.

21. Distribution of US Medical School Faculty by School and Department Type. Association of American Medical Colleges. Available from: http://www.aamc.org/data/facultyroster/usmsf05/05table2.pdf. Accessed Mar 2006.
22. Grants and Awards. Association of American Medical Colleges. Available from: http://www.aamc.org/about/awards/start.html. Accessed Mar 2006.

23. Accreditation Standards. IS-14-A: Service-Learning. Liaison Committee on Medical Education. Available from: http://www.lcme.org/standard.htm. Accessed Aug 2007.

24. Okasha A. Settings for learning: the community beyond. Med Educ. 1995;29 Suppl 1:112-115.

25. Seifer SD. Service-learning: community-campus partnerships for health professions education. Acad Med. 1998;73(3):273-277.

26. Clasen A. Defining a mission statement and setting goals. J Calif Dent Assoc. 1994;22(1):29-32.

27. Weiser CJ, Houglum L. Scholarship unbound for the 21 st century. J Extension. 1998;36:1-5.

28. Community-Engaged Scholarship for Health Collaborative. Project Press Release. 2005 Jan. Community-Campus Partnerships for Health. Available from: http://depts.washington.edu/ccph/pdf_files/FIPSE\%20 Press\%20Release.pdf. Accessed Aug 2007.

29. Mullan F, Chen C, Petterson S, Kolsky G, Spagnola M. The social mission of medical education: ranking the schools. Ann Intern Med. 2010;152(12):804-811.

30. Coulehan J, Williams PC, McCrary SV, Belling C. The best lack all conviction: biomedical ethics, professionalism, and social responsibility. Camb Q Healthc Ethics. 2003;12(1):21-38.
Advances in Medical Education and Practice

\section{Publish your work in this journal}

Advances in Medical Education and Practice is an international, peerreviewed, open access journal that aims to present and publish research on Medical Education covering medical, dental, nursing and allied healthcare professional education. The journal covers undergraduate education, postgraduate training and continuing medical education

\section{Dovepress}

including emerging trends and innovative models linking education, research, and healthcare services. The manuscript management system is completely online and includes a very quick and fair peer-review system. Visit http://www.dovepress.com/testimonials.php to read real quotes from published authors.

Submit your manuscript here: http://www.dovepress.com/advances-in-medical-education-and-practice-journal 